\title{
OPTICAL SPECTROSCOPIC METHODS FOR DIAGNOSTICS OF INTERVERTEBRAL DISC DEGENERATION
}

\author{
J.V. Vaitkus ${ }^{\text {a }}$, D. Varanius ${ }^{\text {a, b }}$, I. Čiplys ${ }^{\text {a, b }}$, V. Gėgžna ${ }^{\text {a b b }}$, G. Terbetas ${ }^{\text {d }}$, \\ J. Ušinskiené ${ }^{c}$, and A. Vaitkuviené ${ }^{a}$ \\ ${ }^{a}$ Institute of Photonics and Nanotechnology, Vilnius University, Sauletekio 3, 10257 Vilnius, Lithuania \\ ${ }^{\mathrm{b}}$ Institute of Biosciences, Life Sciences Centre, Vilnius University, Sauletekio 7, 10257 Vilnius, Lithuania \\ 'National Cancer Institute, Vilnius University, Santariškiu 1, 08660 Vilnius, Lithuania \\ ${ }^{\mathrm{d}}$ Faculty of Medicine, Vilnius University, M. K. Čiurlionio 21, 03101 Vilnius, Lithuania \\ Email: juozas.vaitkus@ff.vu.lt
}

Received 15 September 2017; revised 10 May 2018; accepted 21 June 2018

\begin{abstract}
The level of degeneration (LOD) in the human intervertebral disc (IVD) could determine the choice of patient treatment strategy, thus there is a need for methods applicable at a point of care that enable quick medical decisions. In this paper, infrared light absorption, FT-Raman scattering and fluorescence spectroscopy were used to analyse the same specimens from different groups of IVD samples.

Samples from the lumbar part of spine of 37 patients (mean age 48.2 years old) were included in the study. The gender distribution was 27 women and 10 men. The distribution by LOD in the Pfirrmann scale was as follows: grade $3(40.5 \%)$, grade $4(48.6 \%)$ and grade $5(10.8 \%)$ were evaluated in our samples. Spectroscopic signals were measured and analysed. Features such as medical condition (LOD), patient's age and gender were taken into account. All three methods of spectroscopy revealed age-dependent spectroscopic features related to LOD. For the first time a promissing possibility was found to recognize the LOD by fluorescence spectra in human IVD material taking gender and age into account. The findings create a background for the design of equipment and the design of experiment of more advanced clinical trials. FT-IR absorption and FT-Raman scattering spectra demonstrated the age dependences of a few components. The Raman peak at $2707 \mathrm{~cm}^{-1}$ seems promising for recognition of lumbar IVD LOD, but a higher number of specimens is necessary.
\end{abstract}

Keywords: optical biopsy, tissue fluorescence, Raman spectroscopy, FT-IR absorption, biomedical diagnostics

PACS: $87.64 . \mathrm{km}, 87.64 . \mathrm{kp}, 87.64 . \mathrm{kv}$

\section{Introduction}

The intervertebral disc (IVD) is a part of the human vertebral column in the spine. More specifically, it is the fibrocartilage that lies between each adjacent bone called spinal vertebra. IVD degeneration is a universally prevalent aging-related pathologic process. If the level of degeneration (LOD) increases, IVD changes in morphology and becomes more and more disorganized. Unfortunately, similar changes occur while the age of a person increases. At early stages of degeneration, nucleus pulposus (NP), an inner gel-like central part of IVD, loses the ability to attract water. At later stages, collagen and elastin fibre remodelling takes place, proteoglycan and chondroitin sulfate amounts diminish, causing anatomical changes in both NP and annulus fibrosus (AF), the fibrous ring of IVD. Gross anatomical changes inside IVD and in adjacent vertebrae also occur. However, for some patients, the degeneration of IVD causes low back pain (LBP). Older age of a patient is associated with an increased incidence of degenerative changes. It is difficult to differentiate between the changes that occur solely due to aging from those that might be considered 
'pathological' [1]. There are many causes of LBP, and it is believed that degenerative disc disease is one of the most prevalent causes of LBP. Degenerated IVD is a common finding in magnetic resonance imaging (MRI) and X-ray (radiographs) scans. Different grading systems have been proposed for research and clinical purposes.

There are several systems for degeneration grading that continue to be developed and used [2, 3], but there is a consensus that, among MRI grading systems, the system described by Pfirrmann et al. [4] should be considered as the gold standard. It was found that the signal loss of the disc on T2 (spin-spin relaxation)-weighted MRIs correlates with the progressive degenerative changes of IVD, and a grading system was proposed for the assessment of lumbar disc degeneration in the form of a simple algorithm using the contemporary MRI technique.

However, rather than quantifying disc degeneration, these measurements are often fused with subjective clinical symptoms to impose treatment decisions [2]. The major limitation of spinal imaging is a weak correlation between imaging findings and clinical symptoms [5, 6. Instead of revealing an apparent source of pain, such as a painful degenerated disc or inflamed facet joint, imaging results reveal common degenerative changes concordant to age [2, , 8] . Despite the limitations of MRI-based systems, they remain the predominant and most sensitive tools for the diagnostics of IVD degeneration [2, 3].

Imaging techniques can provide one with a limited amount of information about IVD degeneration on the tissue level. Due to this drawback, an open surgical disc biopsy of disc samples is needed. The disc material could be then investigated histologically and immunohistochemically. Unfortunately, those methods take time, are invasive, expensive, and do not reveal the actual cause of pain. There remains a need for a straight, objective, minimally invasive diagnostic test for discogenic LBP.

Percutaneous laser disc decompression (PLDD) is one of the so-called 'minimally invasive' treatment modalities for contained lumbar disc herniation. The treatment is performed percutaneously, so morbidity is expected to be lower and the convalescence period is postulated to be shorter than for conventional surgery. Because of the minimal- ly invasive nature and the fact that return to work is usually possible within a few days after treatment, PLDD appears to be an interesting alternative to conventional surgery; however, still there is considerable skepticism about PLDD. Opponents usually dismiss PLDD as being an experimental treatment with unproven efficacy, whereas those advocating the use of PLDD tend to present it as some miracle treatment [9].

In PLDD, this mechanism is exploited by application of laser energy to evaporate water in the NP. A laser fibre delivers laser energy through a hollow needle placed into the NP. Apart from evaporation of water, the increase in temperature also causes protein denaturation and subsequent renaturation. This causes a structural change of the NP, limiting its capability to attract water and therefore leading to a permanent reduction of intradiscal pressure by $\leq 57 \%$ [9].

'Optical biopsy' is a somewhat novel method that uses spectroscopy at selected wavelengths to diagnose the disease, and the focus has been on diseases such as cancer and atherosclerosis without removing tissue from the body [10]. These measurements provide a possibility to analyse a contribution of the main native molecules in tissues and to reveal differences between malignant and normal tissues due to morphological and molecular changes in various tissues. The primary optical methods for recognition of molecules are infrared (IR) absorption, Raman scattering, luminescence and backscattering reflectance (including time-resolved) spectroscopies, as well as imaging. Different approaches are used to select types of devices for clinical trials, from the point of monitoring [11] to hyperspectral imaging [12].

'Optical biopsy' may be a suitable class of methods to either determine the LOD of IVD or other medical condition. The procedure of either pathological or even painful IVD examination could be performed through an optical fibre and a hollow needle that is used for PLDD without removing any tissue from the body either before the PLDD procedure or during open surgery in the point of care. Several different spectroscopic methods of tissue analysis are under development. The autofluorescence phenomenon allows differentiating between traumatized and degenerated disc tissue intraoperatively, and in some cases, it also allows differentiating between the bone and collagen 
endplate in cervical disc surgery [13], the fluorescence spectroscopy demonstrated a possibility to analyse the LOD [14]. It is well known that Raman scattering and IR absorption spectra allow tracking biochemical changes in the tissue.

Raman spectroscopy provides spectral information based on the vibrational and rotational modes of molecular species in the tissue. It leverages the inelastic scattering of incident near-infrared laser light to enable the noninvasive in vivo analysis of tissue and allows not only the identification of different molecular species but also the determination of their relative concentration [15].

The primary purpose of this paper is to analyse the possibilities of fluorescence, Fourier-transform infrared (FT-IR) absorption and Fourier transform Raman (FT-Raman) scattering spectroscopies for IVD pathology detection. Also, for the first time a promissing possibility was found to recognize the LOD by fluorescence spectra in human IVD material. The findings create a background for the design of equipment and the design of experiment of more advanced clinical trials.

\section{Methods}

The investigation was performed in accordance with the requirements of biomedical ethics.

\subsection{Specimens}

MRI scans of preoperative patients were obtained and used to evaluate the LOD according to the Pfirrmann et al. [4] disc degeneration classification system. Personal information of patients such as age and gender was obtained as well. Native disc specimens were removed during an open lumbar disc surgery procedure, frozen to $-20^{\circ} \mathrm{C}$ and cut into $20-\mu \mathrm{m}$-thick slices using a cryo-microtome. Medically the localization of specimens is denoted as L2-3 through to L5-S1 in the lumbar section. Slices of specimens were placed on the calcium fluoride $\left(\mathrm{CaF}_{2}\right)$ substrate for FT-IR, FT-Raman scattering, and fluorescence spectroscopies. The measurements were performed within $48 \mathrm{~h}$ after removal.

A total of 37 patients were included in the study: $27(73.0 \%)$ women and $10(27.0 \%)$ men. The mean age of the patients was 48.2 years. The distribu- tion of samples by LOD was as follows: 15 samples (40.5\%) of Pfirrmann grade 3, 18 samples (48.6\%) of grade 4 and 4 samples (10.8\%) of grade 5 were evaluated in our study.

\subsection{Spectroscopic signal acquisition and data analysis}

Raman scattering spectra of IVD tissue samples were excited with the $1064 \mathrm{~nm}$ radiation of a Nd:YAG (neodymium-doped yttrium aluminum garnet; $\mathrm{Nd}: \mathrm{Y}_{3} \mathrm{Al}_{5} \mathrm{O}_{12}$ ) laser and recorded with a modern FT-Raman spectrometer MultiRAM (Bruker Optik GmbH, Ettlingen, Germany). The spectra were recorded in the $400-3600 \mathrm{~cm}^{-1}$ spectral range.

Infrared (IR) absorption was registered by an IR microscope Hyperion 3000 combined with a FTIR spectrometer Vertex 70 (Bruker Optik GmbH, Ettlingen, Germany) in the $400-3600 \mathrm{~cm}^{-1}$ spectral range. For both FT-IR and Raman scattering measurements the $2-5 \mathrm{~cm}^{-1}$ spectral resolution was used, and the spectra were registered from at least three areas per each sample.

Luminescence spectra were registered through a fibre-based optical system. The pulsed $355 \mathrm{~nm}$ ultraviolet radiation (3rd harmonic of Nd:YAG laser, pulse duration $0.5 \mathrm{~ns}$, repetition rate $10 \mathrm{kHz}$ ) of a microlaser STA-01-TH (Standa Ltd., Vilnius, Lithuania) was used to excite fluorescence. A USB2000 spectrometer (Ocean Optics Ltd., Dunedin, FL 34698, USA) registered the signal in the range from 340 to $1000 \mathrm{~nm}$. Autofluorescence spectra were registered from up to 10 points per one specimen.

Computer programs OPUS 6.5 (Bruker Optik $\mathrm{GmbH}$, Ettlingen, Germany), OriginPro 8 (OriginLabs Corporation, Northampton, USA) and $\mathrm{R}$ ( $R$ Foundation for Statistical Computing, Vienna, Austria) [16] were used to process and analyse the data.

\subsection{FT-IR and FT-Raman data analysis}

A curve fitting procedure with several Gaussian curves (multi-Gaussian fit model) was applied to describe bands in FT-Raman scattering and FT-IR absorption spectra formally. Three parameters can fully describe each Gaussian curve: the position of curve center $x c$, the full width at half maximum 
(FWHM) $w$ and the area under the Gaussian curve A. Positions of the components were analysed to identify possible materials and chemical bonds that contributed to the spectra of the signals. The analysis of the ratios of areas under several Gaussian components (area ratio analysis) was performed to investigate if there were relations between shapes of spectra and various patient and medical condition-related features.

\subsection{Autofluorescence data analysis}

The fluorescence spectra were preprocessed in several steps. First, the relative intensities of each registered spectrum were corrected by the spectrum of optical system sensitivity. This spectrum was obtained by a calibrated Bentham light source with a current stabilized power supply Bentham 607 (Bentham Instruments Ltd., Berkshire, United Kingdom). Second, the mean value of spectra at $750 \sim 800 \mathrm{~nm}$ was calculated as an offset of the $y$ axis, and this offset was removed. Third, the spectra were smoothed by a combination of two filters: a Savitzky-Golay filter (the order of the polynomial is 9, and the length of the filter is 35 points) and a median filter (the length of the filter is 9 points) as well as binning and averaging every 10 points on the wavelength axis. Fourth, as the comparison of absolute intensities was impossible due to the transforms of samples during the drying procedure, the spectra were normalized to the intensity at a chosen wavelength. A specific operation was performed to find the optimal normalization wavelength. All possible normalization wavelengths were tried, and the highest values of a classification performance measure called balanced accuracy (BA) were calculated in four spectral ranges (370-400, 400$500,500-600,600-700 \mathrm{~nm})$. The dependence of the maximum $B A$ value in each range on a specific normalization wavelength is plotted in Fig. 2. Normalization points at 386 and $548 \mathrm{~nm}$ were chosen as the most appropriate ones. Fifth, the spectral range between 370 and $700 \mathrm{~nm}$ was selected for further analysis: the range below $370 \mathrm{~nm}$ was distorted by an optical laser-cut filter and the range above $700 \mathrm{~nm}$ had a low intensity which is almost equal to zero. Lastly, in addition to fluorescence intensity spectra, a dataset of the first-order gapsegment derivatives [17] for each spectrum $(\mathrm{d} I / \mathrm{d} \lambda)$ was obtained and used in the analysis.

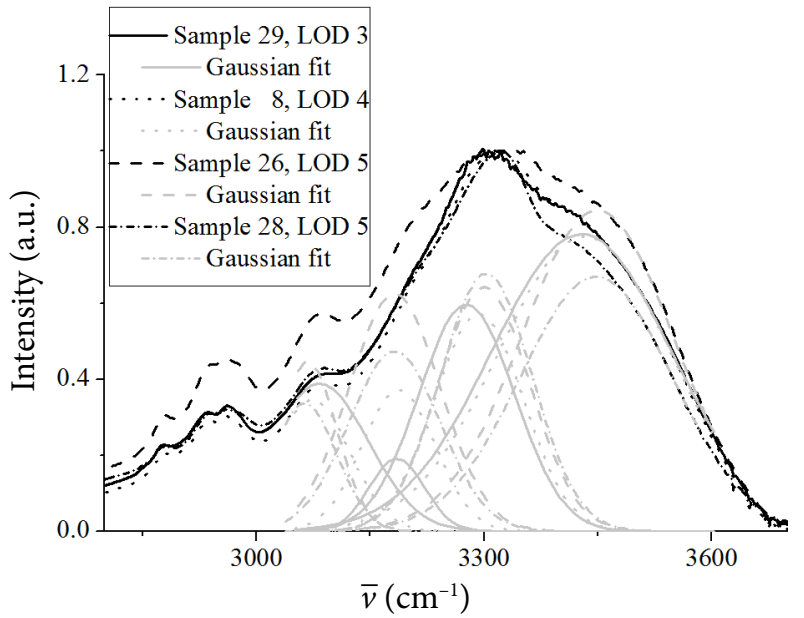

Fig. 1. The approximation of a spectroscopic signal with a model of four Gaussian components in a few samples representing different levels of degeneration (LOD). The parameters of the Gaussian components and the characteristics of the samples are given in Table 1.

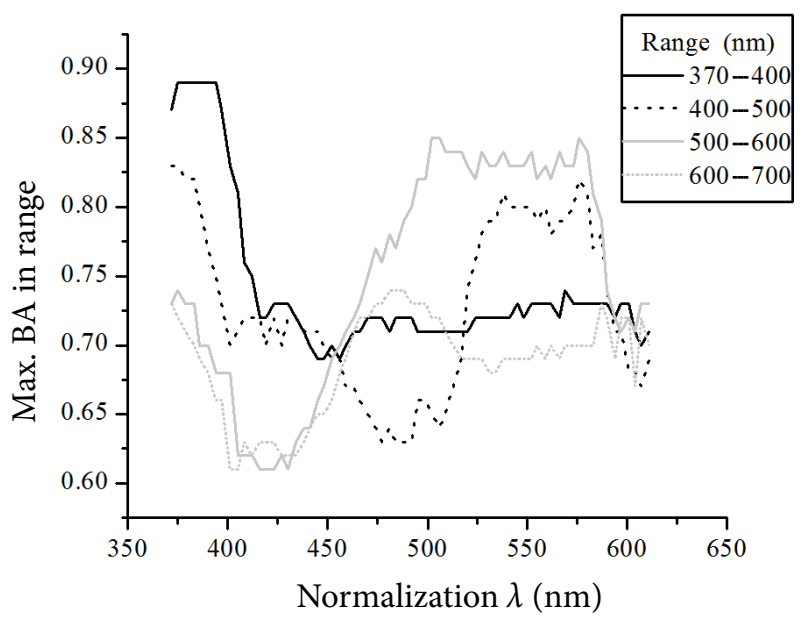

Fig. 2. The dependence of classification performance on the wavelength of spectra normalization: an example. The dependence of the highest balanced accuracy (BA) values in four specific wavelength ranges on the wavelengths of normalization is illustrated with the comparison of $3 \mathrm{rd}$ vs 4 th levels of degeneration in the subset of women that are older than 40 years.

The pre-processed autofluorescence signals were compared to medical and patient-related information at each wavelength separately (EWS). The receiver operating characteristic (ROC) analysis was used to compare the data groups at EWS. The mean of discrimination sensitivity and specificity (also known as balanced accuracy, BA) was used as a classification performance measure [18, 19$]$. 
Table 1. The parameters of the multi-Gaussian fit model: $x c_{i}$, position of $i$ th Gaussian component centre (in $\mathrm{cm}^{-1}$ ); $w_{i}$, full width at half maximum (FWHM) of the $i$ th component; $A_{i}$, area under the Gaussian curve of the $i$ th component; $\mathrm{Chi}^{2} / \mathrm{DoF}$, chi square statistic divided by degrees of freedom; $R^{2}$, coefficient of determination.

\begin{tabular}{cccccc}
\hline Sample No. & 29 & 8 & 26 & 28 \\
\hline LOD & 3 & 4 & 5 & 5 \\
\hline $\mathrm{Chi}^{2} / \mathrm{DoF}$ & $3 \cdot 10^{-5}$ & $2 \cdot 10^{-5}$ & $8 \cdot 10^{-5}$ & $8 \cdot 10^{-5}$ \\
\hline$R^{2}$ & 0.9994 & 0.9996 & 0.998 & 0.998 \\
\hline$x c_{1}$ & $3276.9 \pm 0.2$ & $3293.0 \pm 0.0$ & $3303.0 \pm 0.1$ & $3299.8 \pm 0.1$ \\
\hline$w_{1}$ & $125.9 \pm 0.5$ & $117.4 \pm 1.2$ & $120.0 \pm 0.0$ & $120.0 \pm 0.0$ \\
\hline$A_{1}$ & $94.2 \pm 0.8$ & $84.3 \pm 2.4$ & $102.0 \pm 0.1$ & $96.8 \pm 0.1$ \\
\hline$x c_{2}$ & $3428.2 \pm 0.3$ & $3432.2 \pm 1.3$ & $3447.5 \pm 0.1$ & $3449.1 \pm 0.1$ \\
\hline$w_{2}$ & $236.5 \pm 0.4$ & $226.7 \pm 1.7$ & $200.0 \pm 0.0$ & $200.0 \pm 0.0$ \\
\hline$A_{2}$ & $231.7 \pm 0.6$ & $220.4 \pm 2.5$ & $167.8 \pm 0.1$ & $211.7 \pm 0.1$ \\
\hline$x c_{3}$ & $3083.2 \pm 0.3$ & $3073.5 \pm 0.9$ & $3063.5 \pm 0.1$ & $3067.7 \pm 0.1$ \\
\hline$w_{3}$ & $129.1 \pm 1.6$ & $98.6 \pm 3.2$ & $84.2 \pm 0.2$ & $75.6 \pm 0.2$ \\
\hline$A_{3}$ & $62.9 \pm 0.8$ & $42.7 \pm 1.7$ & $35.6 \pm 0.1$ & $35.6 \pm 0.1$ \\
\hline$x c_{4}$ & $3184.9 \pm 0.3$ & $3187.3 \pm 1.3$ & $3182.0 \pm 0.0$ & $3182.0 \pm 0.0$ \\
\hline$w_{4}$ & $72.4 \pm 0.7$ & $96.9 \pm 1.6$ & $120.0 \pm 0.0$ & $120.0 \pm 0.0$ \\
\hline$A_{4}$ & $17.4 \pm 0.6$ & $45.2 \pm 1.3$ & $71.3 \pm 0.1$ & $94.1 \pm 0.1$ \\
\hline
\end{tabular}

Several grouping features (LOD, gender and age groups) were used. At first, only the LOD was used. Next, the dataset was split into four subsets according to age and gender groups. The analysis was repeated in each subset at EWS.

All presented results in the tables were statistically significant, the $p$-value for all data was less than 0.05 .

\section{Results}

During the period of investigation, 37 specimens were obtained. A dataset based on these samples contained medical information (such as patient's age, gender and LOD) as well as spectroscopic information (FT-IR absorption, FT-Raman scattering and autofluorescence spectra).

\subsection{FT-IR spectra}

Various types of spectra and a set of spectroscopic features are demonstrated in Fig. 3 .

In the FT-IR absorption spectra, the wellknown spectral lines [20, 21] such as amide I (1655 $\mathrm{cm}^{-1}$ corresponding to the $\mathrm{C}=\mathrm{O}$ stretching vibration), amide II $\left(1550 \mathrm{~cm}^{-1}, \mathrm{C}-\mathrm{N}\right.$ stretch, $\mathrm{N}-\mathrm{H}$ band combination) and amide III $\left(1240 \mathrm{~cm}^{-1}, \mathrm{C}-\mathrm{N}\right.$ stretch, $\mathrm{N}-\mathrm{H}$ bend, $\mathrm{C}-\mathrm{C}$ stretch), which are present in collagen and elastin, could be seen clearly. The amide III band at $1205 \mathrm{~cm}^{-1}$ represents collagen, and elastin contributes to the $1340-1450 \mathrm{~cm}^{-1}$ band with a band at $1400 \mathrm{~cm}^{-1}$. Chondroitin sulfate might contribute to the $1240 \mathrm{~cm}^{-1}$ band. As the degeneration and aging of discs are associated with the $\mathrm{O}-\mathrm{H}$ related bonds $\left(3200-3640 \mathrm{~cm}^{-1}\right)$, the analysis of $3080-3640 \mathrm{~cm}^{-1}$ range showed it was composed of amide A $(\mathrm{N}-\mathrm{H}$ stretching vibration at 3225 and $3280 \mathrm{~cm}^{-1}$ and $\mathrm{C}-\mathrm{H}$ stretching vibration at $\left.2780-2984 \mathrm{~cm}^{-1}\right)$. The spectra of IVD samples did not show any spectral shape dependence on the LOD. As the process of degeneration is known to be related to the loss of water (and $\mathrm{O}-\mathrm{H}$ related components) in the discs [22], the analysis of the $3080-3640 \mathrm{~cm}^{-1}$ spectral range was performed in more detail. All spectra were decomposed into four Gaussian components with the central values at approximately $3083(\mathrm{C}-\mathrm{H}$ stretch), 3182, 3293 and $3456 \mathrm{~cm}^{-1}$. The bands at 3182 and $3293 \mathrm{~cm}^{-1}$ involve the contribution of amide $\mathrm{A}$, and the band at $3456 \mathrm{~cm}^{-1}$ is related to $\mathrm{O}-\mathrm{H}$ bonds.

The area ratio analysis revealed the scattering of the values that are illustrated in Fig. 4(a), and it introduced a necessity to analyse how these 

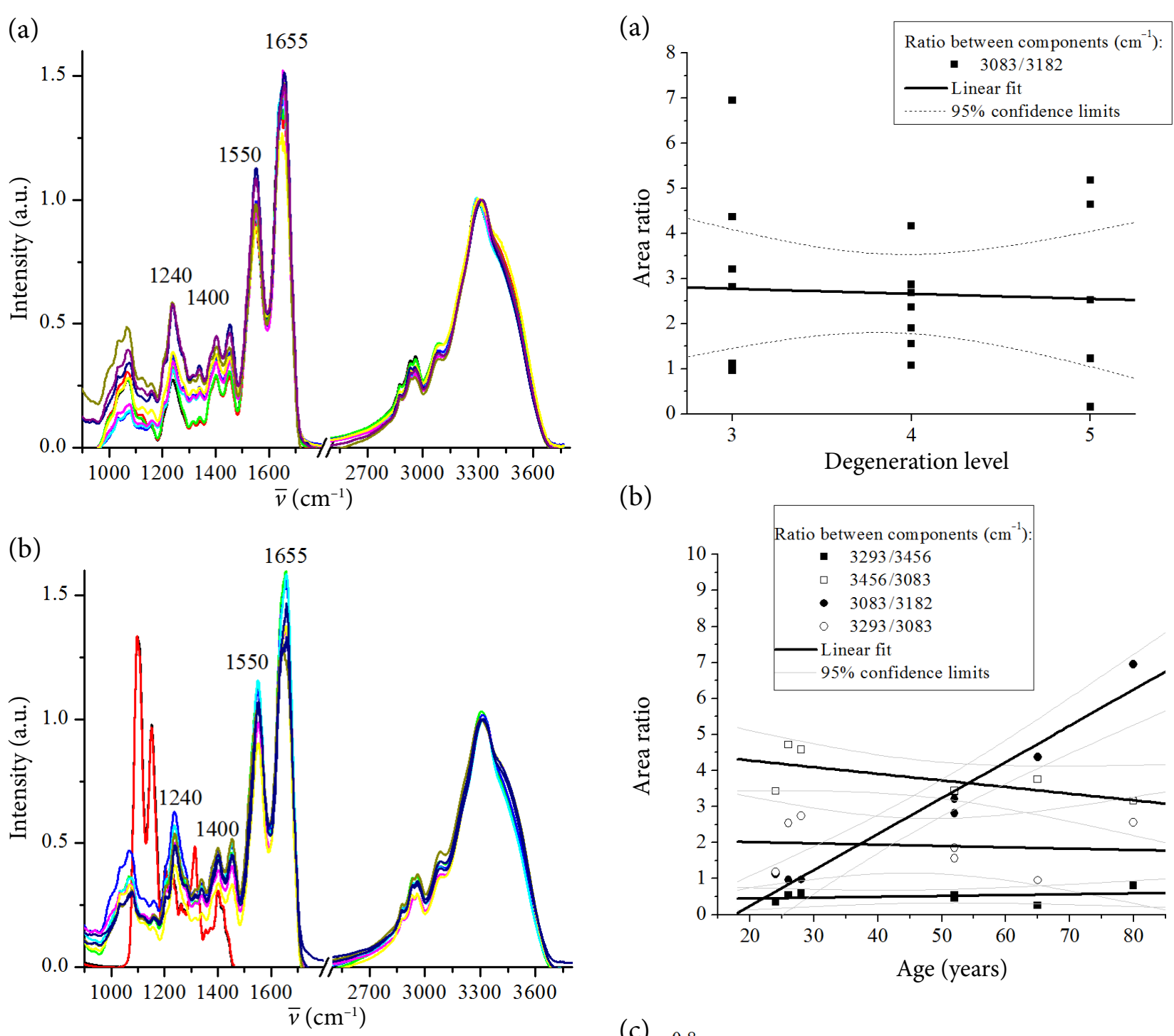

(b)
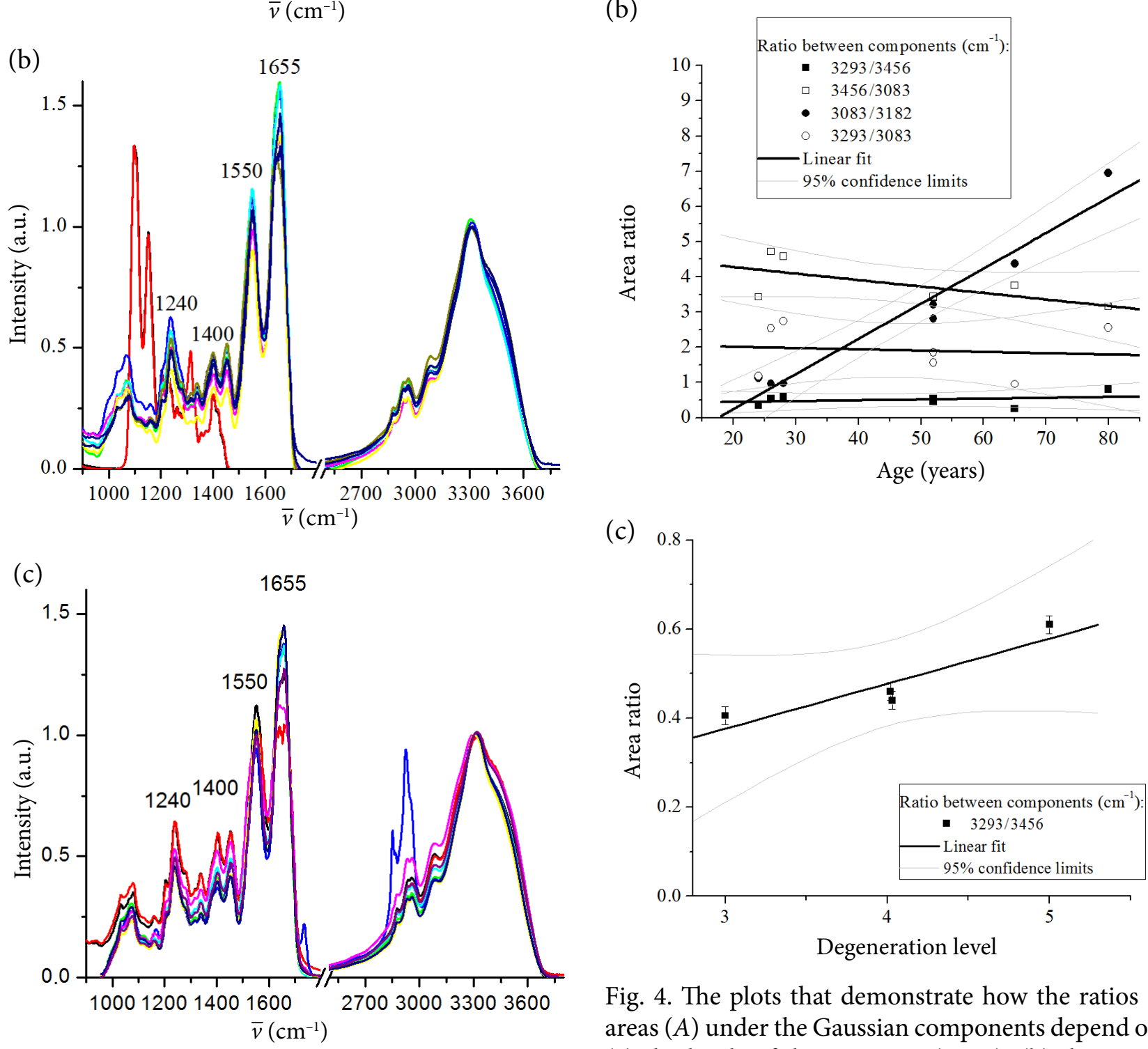

(c)

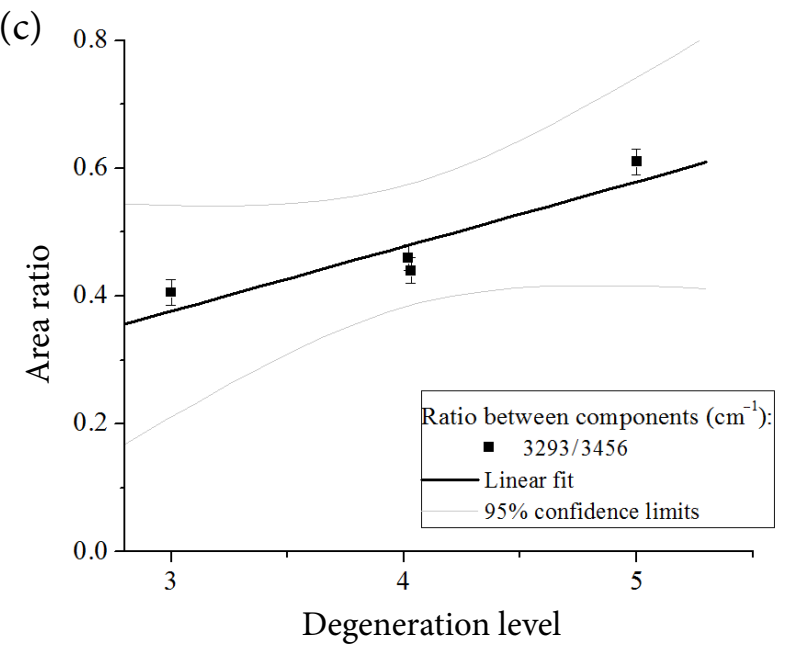

Fig. 4. The plots that demonstrate how the ratios of areas $(A)$ under the Gaussian components depend on: (a) the levels of degeneration (LOD), (b) the age of patients who are diagnosed with the 3rd level of degeneration, (c) the LOD in the samples from the patients of similar age (age 39-47 years old). The ratios are plotted on the $y$ axis. The values of component centres are given in the legends.

Fig. 3. The FT-IR absorption spectra of the samples with different levels of degeneration (LOD): $3 \mathrm{rd} \mathrm{lev-}$ el (a), 4th level (b), and 5th level (c). Several spectra were registered from one sample. The main peak values are indicated above the peaks. 
ratios depend on age. It confirmed that aging is an important factor [2, 月, 8] (Fig. 4(b)) and that both the age and the increase in LOD decreased the contribution of $\mathrm{O}-\mathrm{H}$ related components. If the age component was taken into account (Fig. 4(c)), the decline in $\mathrm{O}-\mathrm{H}$ related bonds would be found in samples with higher LOD.

Figure 1 and Table 1 demonstrate the similarity of the Gaussian components measurement in a few samples. It was found that in other samples the area ratios of $\mathrm{O}-\mathrm{H}$ related and other components differed up to $50 \%$. It means that $\mathrm{O}-\mathrm{H}$ related bonds depend not only on age and LOD but also on other processes in the spine.

\subsection{FT-Raman spectra}

Various types of spectra and a set of spectroscopic features are shown in Fig. 5. In this work, the authors used two spectra normalization methods. Spectra normalized at $1662 \mathrm{~cm}^{-1}$ to reveal the changes corresponded to amide $\mathrm{I}$, and to scattering by the substrate $\mathrm{CaF}_{2}$ to compare the absolute scattering intensity values. The spectra of samples in each group were somewhat different, and the intensities of various bands were scattered without any evident relation to the LOD.

The FT-Raman scattering spectra (Fig. 5) demonstrated a few well-expressed bands. The bands at $2700-3300 \mathrm{~cm}^{-1}$ are related to $\mathrm{C}-\mathrm{H}$ stretch responses [23], and the prominent $\mathrm{C}-\mathrm{H}$ stretching bands in the range of $2870-2975 \mathrm{~cm}^{-1}$, most likely originating from the $-\mathrm{CH}_{3},>\mathrm{CH}_{2}$, and $\mathrm{C}-\mathrm{H}$ functional groups in amino acid side chains of proteins, lipids and carbohydrates, and the components strongly overlap. The band at $2707 \mathrm{~cm}^{-1}$ could be related to the $\mathrm{C}-\mathrm{H}$ stretched bonds in biomembrane lipids [20, 24, 25], and as it did not overlap with other bands, the behaviour of its intensity in different degeneration samples was analysed and presented in Fig. 6. In the $1200-1800 \mathrm{~cm}^{-1}$ region, the amide I and amide III bands of proteins give rise to a weak band around $1662 \mathrm{~cm}^{-1}$, and the dependence of this band on the sample tissue LOD is presented in Fig. 6. Bands in the $1050-1150 \mathrm{~cm}^{-1}$ region with the main bands at 1056, 1091 and $1118 \mathrm{~cm}^{-1}$, on the one hand, could be attributed to the biological membranes of IVD cells. Biological membranes are heterogeneous assemblies composed of various phospholipids differing in their chemical structure.
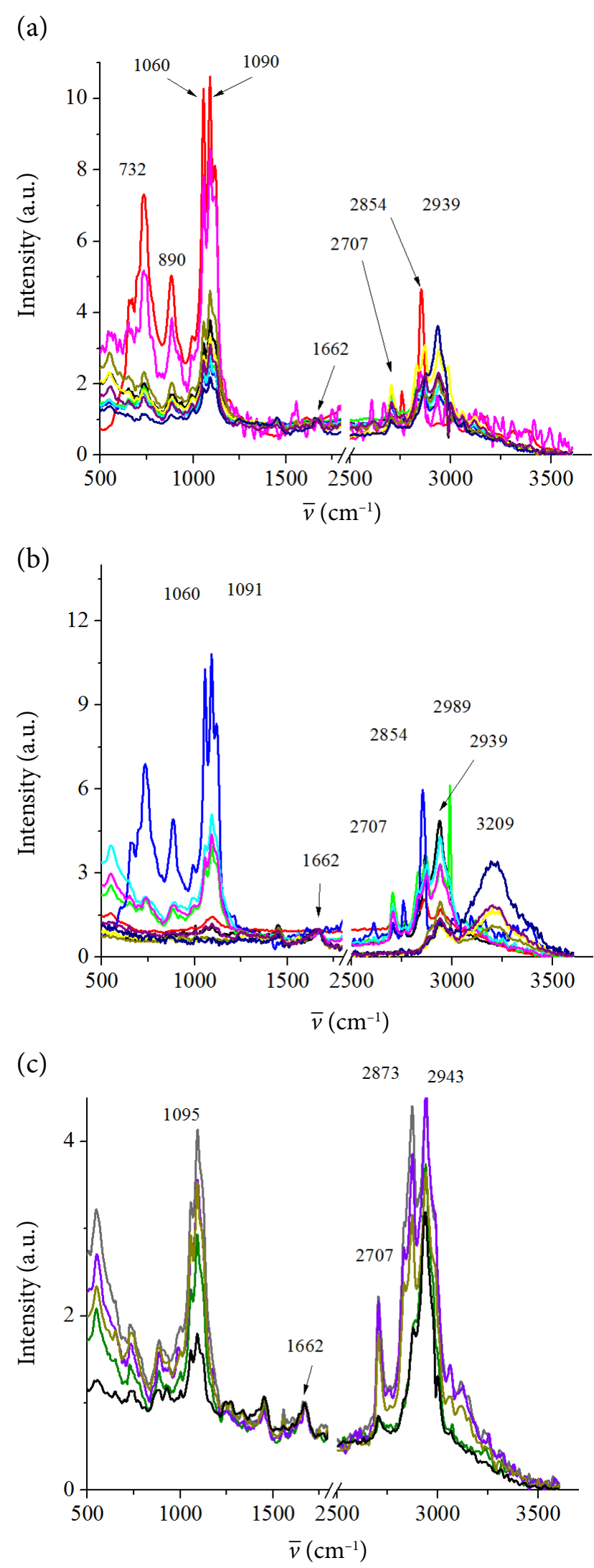

Fig. 5. Raman scattering spectra of the samples with different levels of degeneration: 3 rd level (a), 4th level (b) and 5th level (c). The spectra are normalized at $1662 \mathrm{~cm}^{-1}$. The main peak values are indicated above the peaks. 

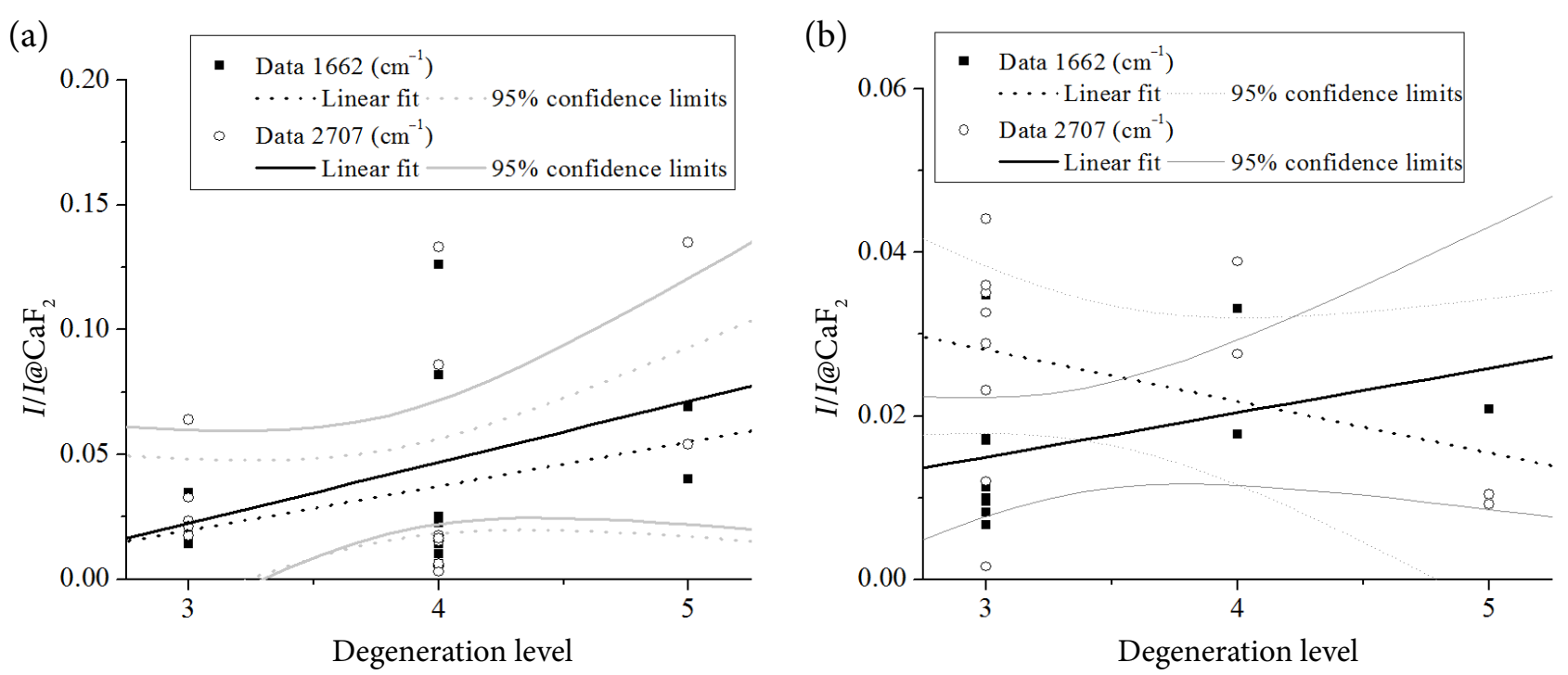

Fig. 6. The dependences of Raman scattering intensity on the levels of degeneration (LOD) in a subset of women (a) and in a subset of men (b). The spectra are normalized to the peaks of $\mathrm{CaF}_{2}$ band at $1662 \mathrm{~cm}^{-1}$ and $2707 \mathrm{~cm}^{-1}$. The details of the curves are given in the legends.

According to this fact, phosphatidylethanolamine (PE) contains fatty acids with more unsaturated carbon chains than phosphatidylcholine (PC). At the lower wavenumber range of $\mathrm{PC}$ and $\mathrm{PE}$ spectra, the $\mathrm{C}-\mathrm{C}$ stretching mode appears as the broadband centred at approximately $1090 \mathrm{~cm}^{-1}$ [26]. In agreement with the literature, in the spectrum of $\mathrm{PC}$, this band is composed of two counterparts at 1062 and $1090 \mathrm{~cm}^{-1}$ and the shoulder at $1125 \mathrm{~cm}^{-1}$ [27]. In our samples, the wavenumber values of these bands in different spectra are scattered within a range of $5 \mathrm{~cm}^{-1}$.

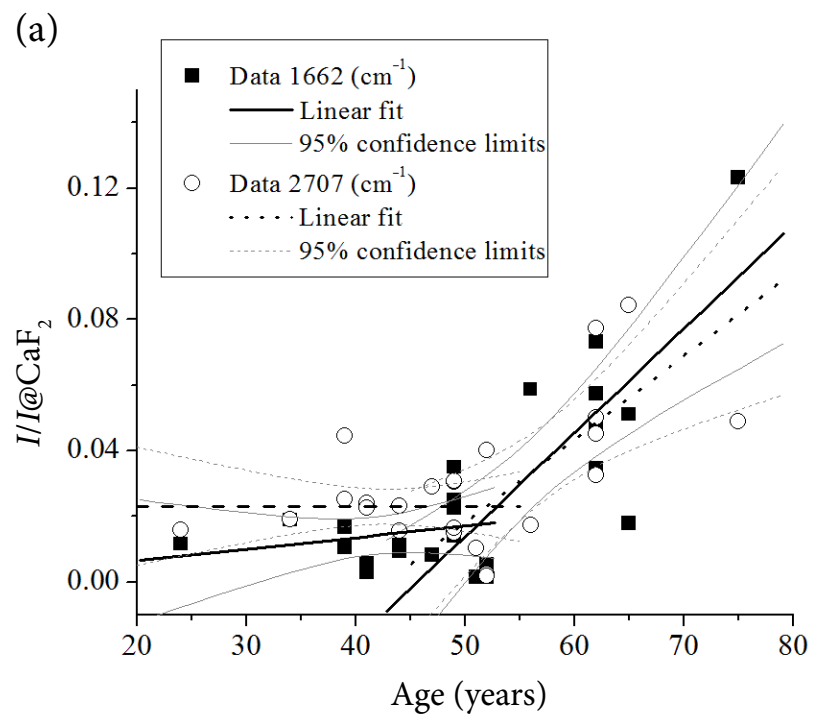

The results of analysis of the band intensity dependence on the patient age and the tissue LOD were not satisfactory except two cases. A well-expressed band was found at $2707 \mathrm{~cm}^{-1}$, and the intensity of this band tended to depend on the LOD (Fig. $6(a, b))$ together with the behaviour of the amide I $\left(1662 \mathrm{~cm}^{-1}\right)$ band. The dependence of intensity of both bands on the patient age is presented in Fig. 7. In this case, the scattering intensities were compared. Therefore the spectra were normalized to the intensity of the $\mathrm{CaF}_{2}$ band.

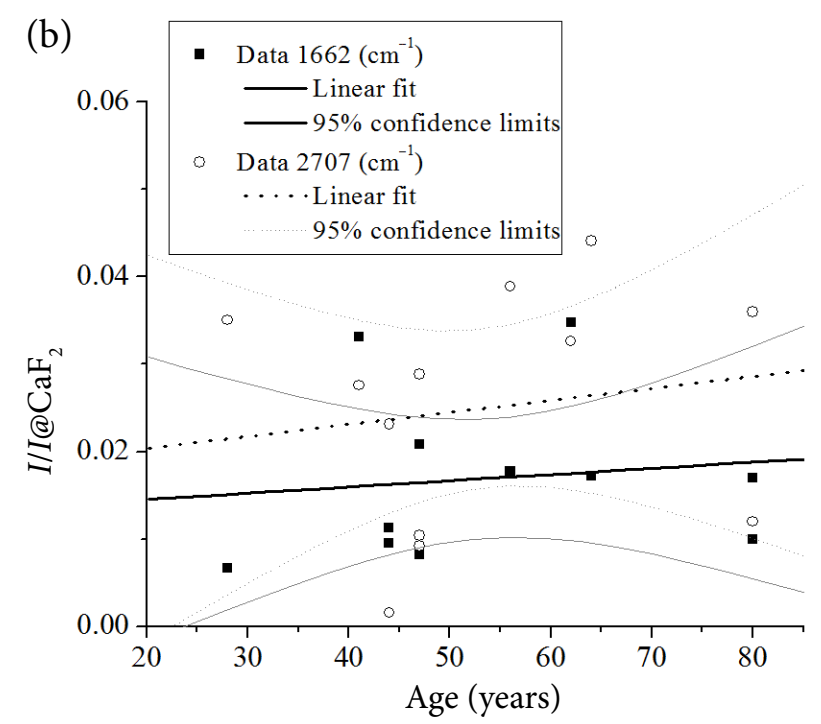

Fig. 7. The dependence of Raman scattering intensity on the age of patients in the subsets of women (a) and men (b). The spectra are normalized to the peak of $\mathrm{CaF}_{2}$ band at $1662 \mathrm{~cm}^{-1}$ and to the peak of amide I band at $2707 \mathrm{~cm}^{-1}$. The details are given in the legends. 


\subsection{Fluorescence spectra}

The analysis of the fluorescence spectra (Fig. 8) was performed by dividing the spectra into groups cor-

(a)

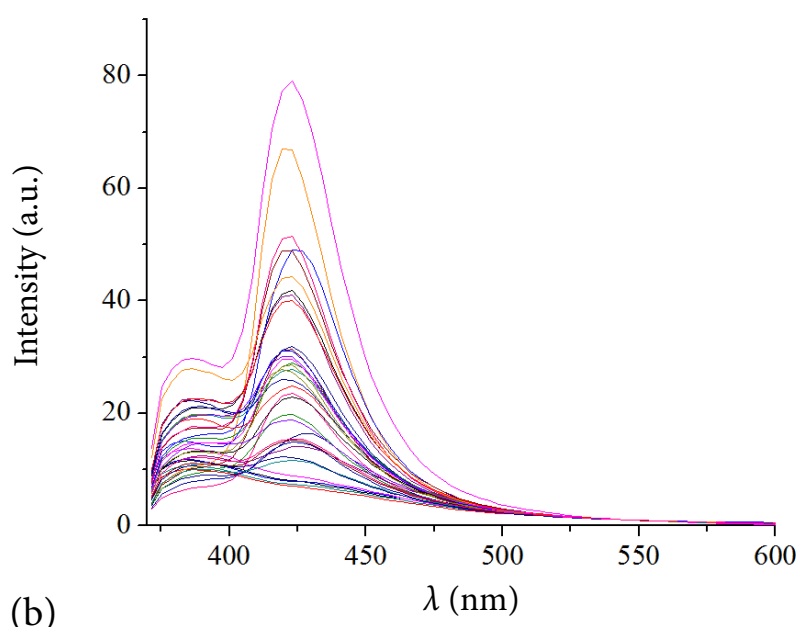

(b)
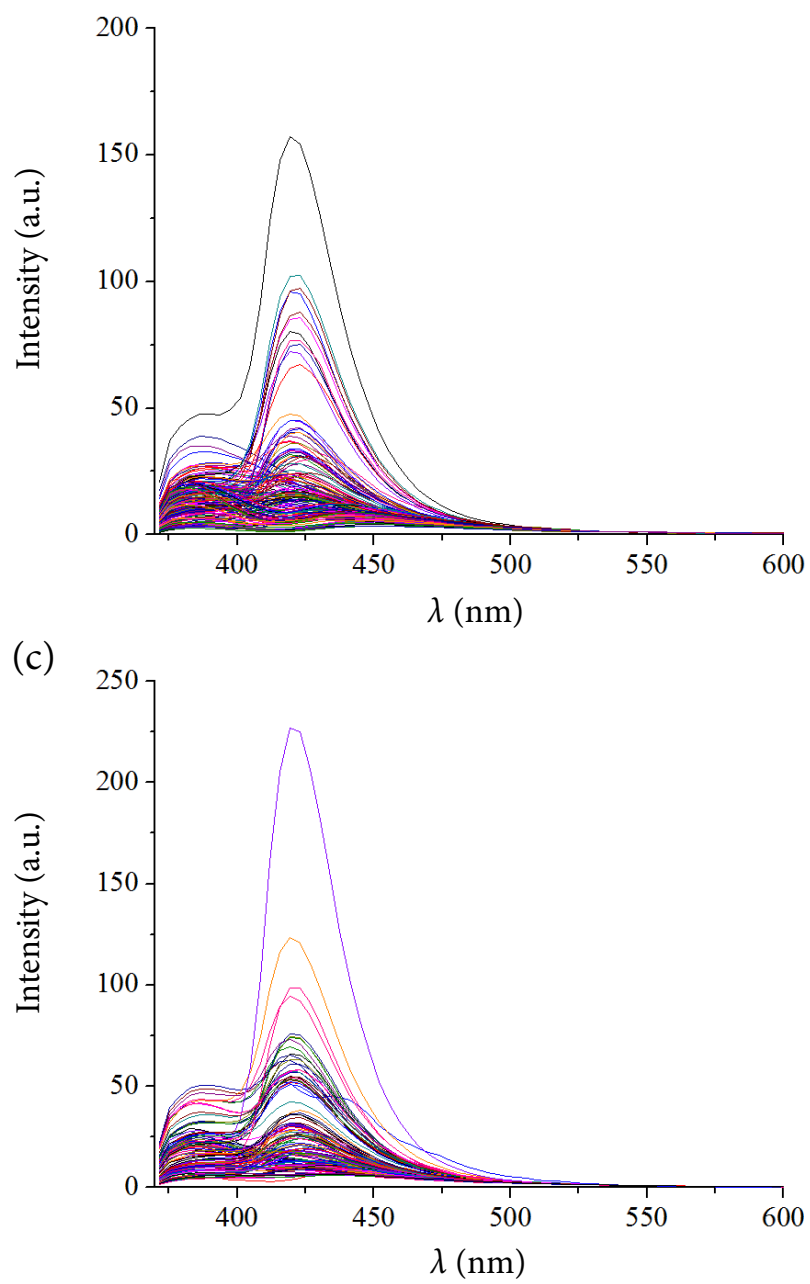

Fig. 8. The fluorescence spectra of the samples with different levels of degeneration (LOD): 3rd level (a), 4 th level (b) and 5th level (c). Several spectra were registered from each sample. The spectra are normalized at $548 \mathrm{~nm}$. responding to the LOD. Differences in the spectra belonging to samples of different LOD were not explicitly expressed as spectra characterized by a high variance, which maybe resulted from additional factors such as gender and age. Based on this assumption, the spectra were divided into age/ gender groups and analysed again. The averages of spectra intensity at EWS within various groups of age and gender are presented in Fig. 9 .
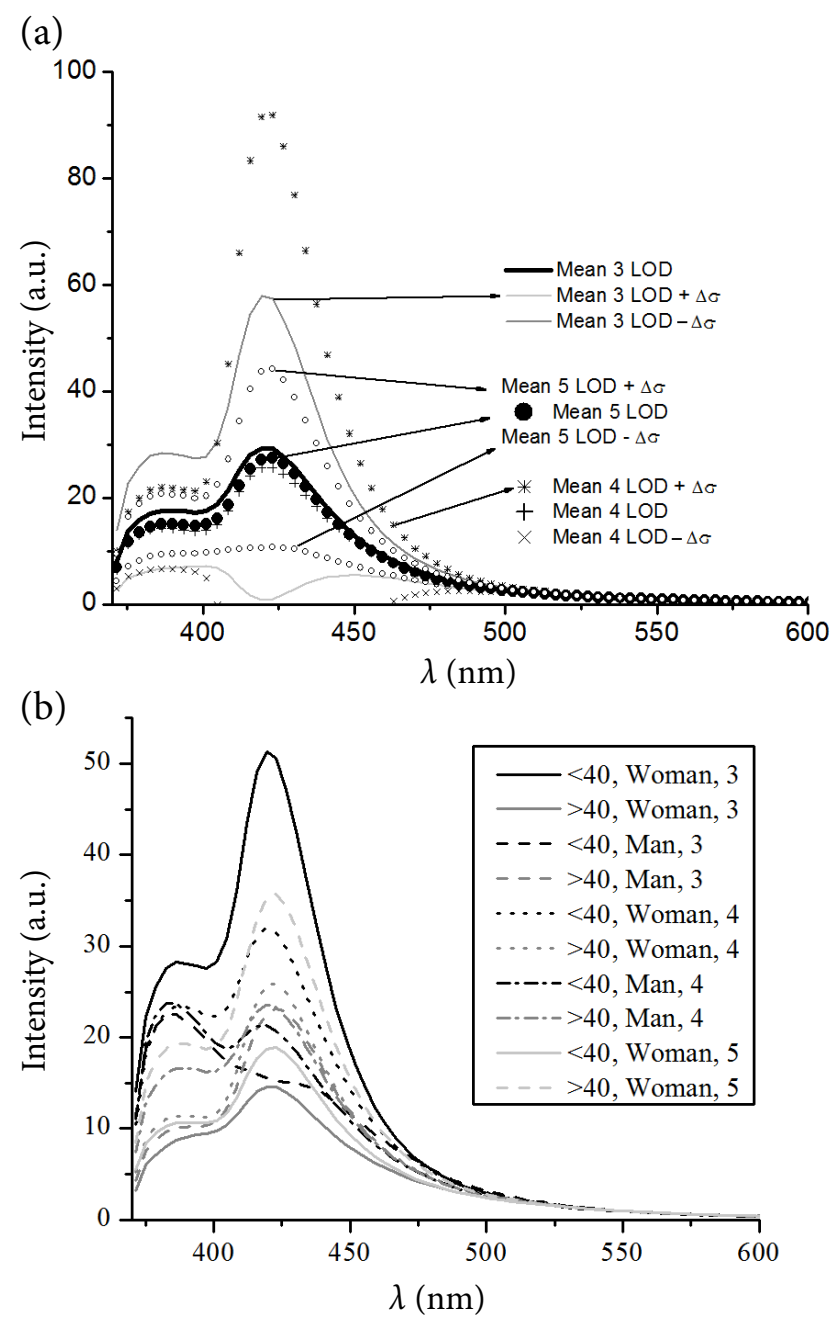

Fig. 9. The fluorescence spectra of IVD samples. (a) The averages and standard deviations of spectra by the LOD groups (the details given in the insets). (b) The averages of spectra in the subsets defined by an age group (above/below 40 years old), gender (man/woman) and $\operatorname{LOD}(3,4,5)$. The spectra are normalized at $548 \mathrm{~nm}$.

It was possible to find out that the main differences between the groups of spectra were in the 380-450 $\mathrm{nm}$ range that corresponds to the elastin and collagen fluorescence region, but 
a quantitative measurement of their contribution was impossible due to the plausible contribution of additional fluorophores. Therefore, the analysis of different LODs identification based on spectroscopic signals was performed, and the age factor was also taken into account. It was found that the BA values for all groups mentioned above were higher than 0.75 (minimum requirement for medical application). In Fig. 10 the dependence of the BA values on the wavelength by comparing fluorescence intensities normalized at $548 \mathrm{~nm}$ is presented and the derivatives of those intensities are analysed.

The classification performance comparing the 3rd and the higher LOD by fluorescence emis-

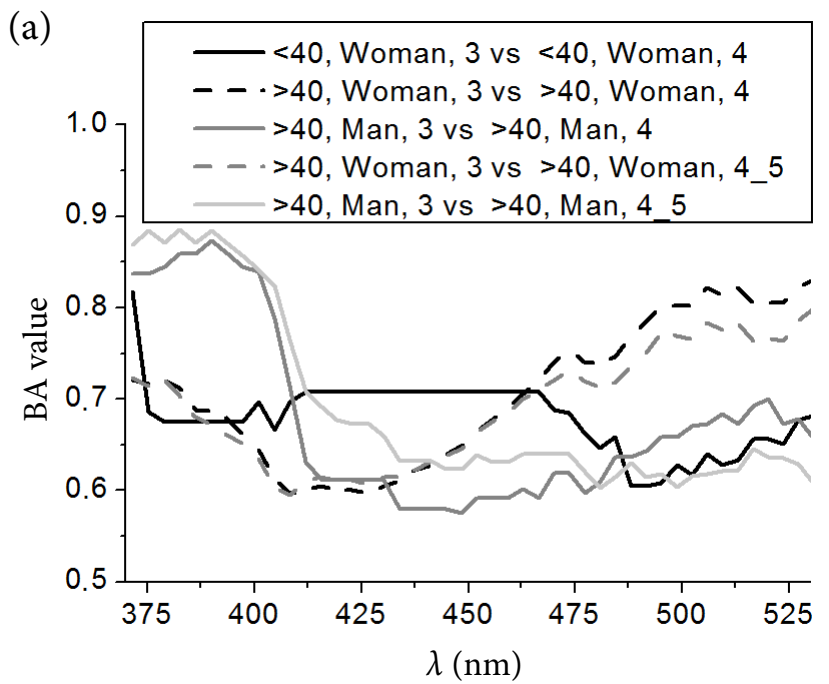

sion intensity in the group of women younger than 40 years at $372 \mathrm{~nm}$ was $\mathrm{BA}=0.82$. The comparison of derivatives at $408 \mathrm{~nm}$ of the same groups resulted in $\mathrm{BA}=0.79 . \mathrm{BA}=0.77$ was achieved comparing derivatives at $394 \mathrm{~nm}$ for women older than 40 years. Comparing the same LOD groups in men older than 40 years by spectra intensity in the 372-394 $\mathrm{nm}$ range the classification performance was $\mathrm{BA}=0.87-0.88$, and comparing by the derivatives at $423 \mathrm{~nm}$ the result was $\mathrm{BA}=0.84$.

The best classification results based on the spectra normalized at $386 \mathrm{~nm}$ are given in Tables 2 and 3 . High enough values of BA were achieved for women older than 40 years, but not for the younger ones.

(b)

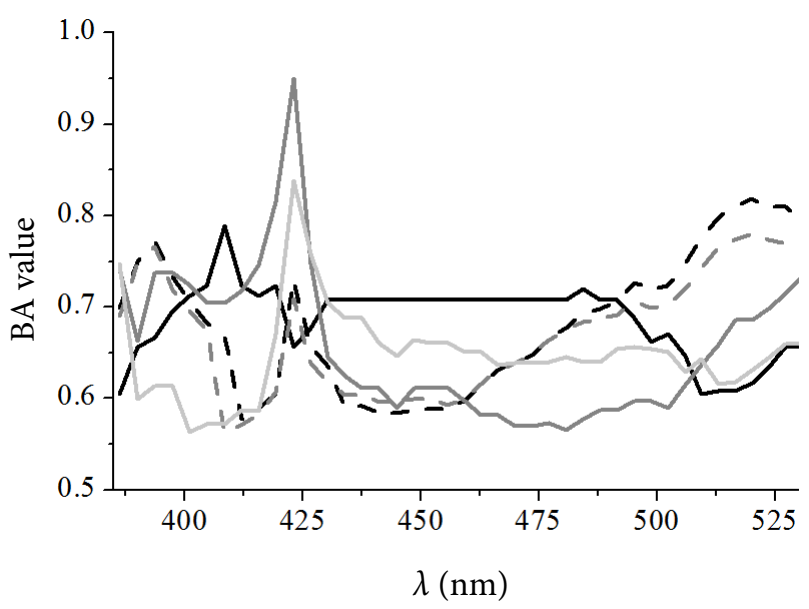

Fig. 10. The dependence of the balanced accuracy (BA) value on the wavelength of the fluorescence signal. The intensities were normalized at $548 \mathrm{~nm}$ (a) and the derivatives of those intensities (b) were analysed.

Table 2. The best balanced accuracy (BA) values comparing each pair of groups that combine various features: age groups (e.g. ' $>40$ ' means above 40 years old), gender (man/woman) and the level of IVD degeneration, LOD (' 3 ' stands for 3rd LOD, ' 4 ' is 4 th LOD, ' $4 \_5$ ' is 4 th and 5 th levels treated as one group). The '@' symbol and the following number point out the wavelength at which the indicated BA value is received. The last column indicates the number of the samples used in the study. The spectra are normalized at $386 \mathrm{~nm}$. The compared spectroscopic feature is the intensities of pre-processed spectra.

\begin{tabular}{|c|c|c|c|c|}
\hline \multirow{3}{*}{ Compared groups } & \multicolumn{3}{|c|}{ The wavelength $(\lambda)$ range of fluorescence spectra } & \multirow{3}{*}{ Number of samples } \\
\hline & $370-400 \mathrm{~nm}$ & $400-500 \mathrm{~nm}$ & $500-600 \mathrm{~nm}$ & \\
\hline & \multicolumn{3}{|c|}{ The best BA@ @ $\lambda, \mathrm{nm}$} & \\
\hline Man.3 vs Man.4 & $0.71 @ 394$ & $0.80 @ 459$ & $0.77 @ 502$ & 5 and 4 \\
\hline$>40$. Woman. 3 vs $>40$. Woman. 4 & $0.89 @ 383$ & $0.80 @ 401$ & $0.70 @ 573$ & 4 and 11 \\
\hline$>40$. Man. 3 vs $>40$. Man. 4 & $0.77 @ 394$ & $0.91 @ 459$ & $0.91 @ 502$ & 4 and 2 \\
\hline Man.3 vs Man.4_5 & $0.70 @ 394$ & $0.78 @ 488$ & $0.77 @ 502$ & 5 and 5 \\
\hline$>40$.Woman. 3 vs $>40$.Woman.4_5 & $0.89 @ 383$ & $0.79 @ 401$ & $0.69 @ 573$ & 4 and 14 \\
\hline$>40$. Man. 3 vs >40.Man. $4 \_5$ & $0.78 @ 394$ & $0.91 @ 488$ & $0.91 @ 502$ & 4 and 3 \\
\hline
\end{tabular}


Table 3. The best BA values comparing each pair of groups that combine various features: age groups (e.g. '>40' means above 40 years old), gender (man/woman) and the level of intervertebral disc degeneration, LOD (' 3 ' stands for 3rd LOD, '4' is 4th LOD, '4_5' is 4th and 5th levels treated as one group). The '@' symbol and the following number point out the wavelength at which the indicated BA value is received. The last column indicates the number of the samples used in the study. The derivative spectra are normalized at $386 \mathrm{~nm}$. The compared spectroscopic feature is the derivatives of pre-processed spectra intensities.

\begin{tabular}{|c|c|c|c|c|}
\hline \multirow{3}{*}{ Compared groups } & \multicolumn{3}{|c|}{ The wavelength $(\lambda)$ range of spectra derivatives } & \multirow[b]{3}{*}{ Number of samples } \\
\hline & $370-400 \mathrm{~nm}$ & $400-500 \mathrm{~nm}$ & $500-600 \mathrm{~nm}$ & \\
\hline & \multicolumn{3}{|c|}{ The best BA@ $\lambda, \mathrm{nm}$} & \\
\hline Man.3 vs Man.4 & $0.70 @ 397$ & $0.79 @ 484$ & $0.79 @ 541$ & 5 and 4 \\
\hline$>40$. Woman. 3 vs $>40$. Woman. 4 & $0.84 @ 386$ & $0.70 @ 401$ & $0.80 @ 587$ & 4 and 11 \\
\hline$>40$. Man. 3 vs >40.Man. 4 & $0.76 @ 397$ & $0.94 @ 423$ & $0.91 @ 502$ & 4 and 2 \\
\hline Man.3 vs Man.4_5 & $0.65 @ 386$ & $0.76 @ 499$ & $0.79 @ 573$ & 5 and 5 \\
\hline$>40$.Woman. 3 vs $>40$.Woman.4_5 & $0.84 @ 386$ & $0.69 @ 405$ & $0.79 @ 587$ & 4 and 14 \\
\hline$>40$. Man. 3 vs $>40$. Man. 4 5 & $0.73 @ 386$ & $0.88 @ 499$ & $0.92 @ 531$ & 4 and 3 \\
\hline
\end{tabular}

\section{Discussion}

It was found that PLDD may provide a noticeable relief in appropriately selected patients with IVD herniations. Therefore methods for recognizing the changes in the IVD are essential for the optimization of treatment. Photodiagnostic investigation of the disc material performed directly before treatment could give additional information on the status of IVD degeneration, and influence decision parameters related to a minimally invasive treatment.

The light absorption in the IR region demonstrated a broad absorption band in the 3200$3500 \mathrm{~cm}^{-1}$ range. This spectral region overlaps with the Erbium:YAG laser emission wavelength of $2940 \mathrm{~nm}$ (or $3401.36 \mathrm{~cm}^{-1}$ ). It could indicate the possibility to use this type of laser for the PLDD treatment. This theory is in agreement with the results of Choy, a PLDD developer who claimed that the most efficient laser regarding energy absorption by water is the Erbium:YAG laser [28]. Moreover, the analysis of the structure of this band also indicated the decrease of the contribution of $\mathrm{O}-\mathrm{H}$ related components with the increase in the age of the patient and the LOD.

The response related to chemical bonds (Raman scattering) demonstrated that only the component at $2707 \mathrm{~cm}^{-1}$ was related to the LOD, other components were not directly related to the LOD. The evident variability of the spectral components amplitude could also be related to other pathologies that exist in the lumbar discs, e.g. Modic changes [29], as well as to the overlap of spectral components discussed above. The later origin of data variability could probably be avoided if a higher spectral resolution would be used, but the application of such devices for diagnosis application would be problematic. The analysis of the IR absorption confirmed a well-known effect of drying as discs with an increased age of the patient and increased LOD lose $\mathrm{O}-\mathrm{H}$ related compounds. The analysis of Raman scattering data revealed the existence of a particular threshold of female age when the amplitudes of the same components change depending on age. The dependence of the component at 1662 and $2707 \mathrm{~cm}^{-1}$ on age was analysed. The component at $1662 \mathrm{~cm}^{-1}$ could be related to amide $\mathrm{I}$ and represent the $\mathrm{C}=\mathrm{O}$ stretching and to a small amount of out-of-phase $\mathrm{C}-\mathrm{N}$ stretching and the component at $2707 \mathrm{~cm}^{-1}$ is proposed to be related to lipids [23,30]. The threshold in the range of women at 40-50 years is observed (Fig. 7a), and it is probably related to hormonal change. This result confirms the earlier data that the transforms of amide I include an amyloid formation that causes the amide I band structure to change [31], and more amyloid was observed in the patient over 50 years [32]. The component at $2707 \mathrm{~cm}^{-1}$ showed a better relation to the LOD, as the dependences on LOD were similar to both genders. The differences of the $1662 \mathrm{~cm}^{-1}$ band are probably related to the overlap of a few components. An example of the structure of the $1662 \mathrm{~cm}^{-1}$ band in our sample is presented in Fig. 11 .

In different samples, the fluorescence spectra were also different, and the recognition of LOD with 


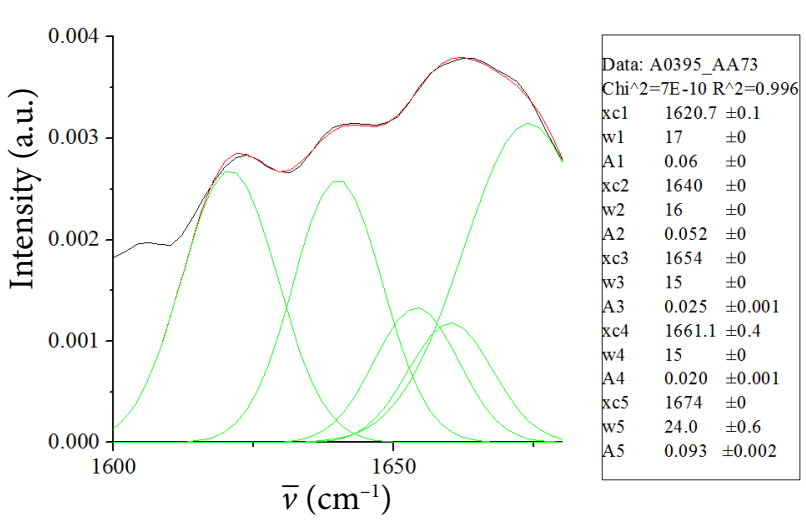

Fig. 11. An example of the amide I band structure in the FT-IR absorption spectra. The Gaussian component parameters are given in the inset.

satisfactory BA was achieved. The data variability not related to the pathology may occur as the luminescence spectrum of tissue is composed of highly overlapping contributions of at least several fluorophores. The main fluorophores such as elastin and collagens emit fluorescence when they are excited by $355 \mathrm{~nm}$ light [14,33]. A fluorescence spectrum would change if any changes in the collagen structure or type happened. The maximum of fluorescence intensity is found at $370 \mathrm{~nm}$ in collagen IV, at $395 \mathrm{~nm}$ in collagen I and V, at $411 \mathrm{~nm}$ in collagen II, at $430 \mathrm{~nm}$ in collagen VII, and at $426 \mathrm{~nm}$ in elastin. Collagen IV has an emission band at $420 \mathrm{~nm}$ as well, and collagen I emits a few more bands at 370, 425, 603 and $660 \mathrm{~nm}$ [33]. Other fluorophores that fluoresce in the same spectral range are also known, e.g. free and bound NADH (bands at 440 and $460 \mathrm{~nm}$ ), and flavins (band at $525 \mathrm{~nm}$ ) [13, 33, 34]. The change in the contribution of a few fluorophores could cause a modification in the shape of the whole fluorescence spectrum of tissue. The input of the fluorophores depends on the tissue composition. It is worth mentioning that the derivative $(\mathrm{d} I / \mathrm{d} \lambda)$ provides one with the information about wavelength-wise change in the intensity of fluorescence thus the derivative of the fluorescence spectrum contains information about a change in the contribution of neighbouring fluorophores.

The results of the fluorescence signal analysis permitted recommending this method for LOD diagnostics. The wavelength, at which the optimum classification performance was achieved, can be related either to the contribution of the fluorophore if the fluorescence intensity was analysed, or to the change in the input of adjacent components if the derivatives of the spectrum were compared. It was impossible to quantify the change in the emission of each tissue fluorophore due to the overlap of contributions of different fluorophores, but it was possible to give qualitative proposals.

As observed, the classification performance to identify LOD depends differently on the age of men and women. Therefore the evaluation of the LOD has to follow the groups presented in Tables 2 and 3 . The presented values of BA show the spectral regions where differences between pathologies exist, and the diagnostic decision can be made by comparing either the pre-processed fluorescence intensity or derivatives of that intensity following the recommendation in Tables2 and 3. The decision on the LOD of the sample corresponds to this value of the intensity (or derivative). In the ROC analysis, the cut-off value for the group discrimination and the average values of the fluorescence intensity in each pathology group were calculated. If the calculated value for a new patient gets on the side (determined by the cut-off) that is closer to the average value of the chosen group, the patient is assigned to this group with the declared BA value. The differences in the values that exceeded the typical (5\%) experimental data error were highlighted in bold in Tables 2 and 3. An example of the comparison of these values is presented in Fig. 12. The average of the preprocessed intensity values and the 'cut-off' values for all letters pointed out in bold in Tables 2 and 3 are presented in Tables 4 and 5 .

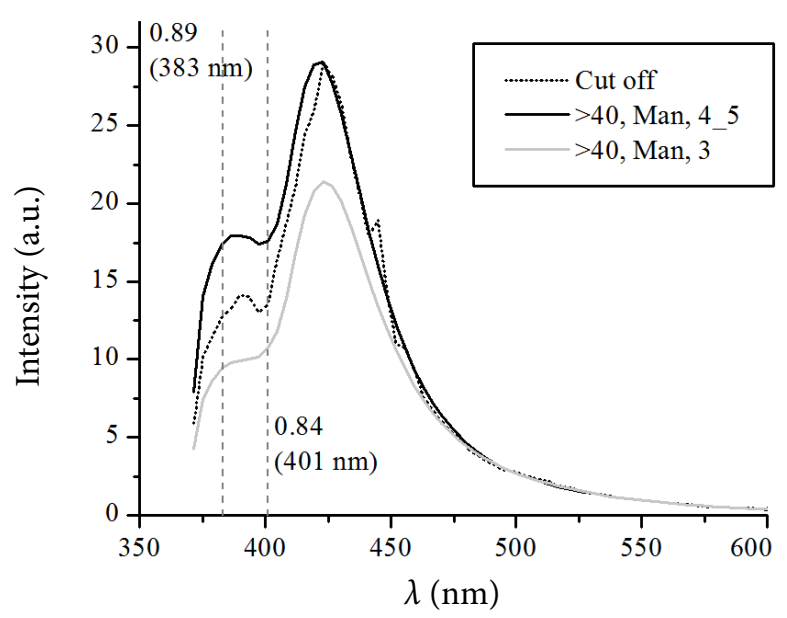

Fig. 12. The average of fluorescence spectra (normalized at $548 \mathrm{~nm}$ ) of the intervertebral disc (IVD) samples in the 3rd (grey curve) vs 4 th and 5th (as one group) LOD (black curve) of the patients above 40 years old, and the cut-off values (a pointed curve) obtained by ROC analysis at every wavelength separately. The vertical lines indicate the highest balanced accuracy values. 
Table 4 . The average values of intensity ratios and 'cut-offs' that are indicated as bold letters in Tables 2 and 3.

\begin{tabular}{c|c|c|ccccc}
\hline Parameter & $\begin{array}{c}\text { Man 3 vs 4 (1) } \\
\text { vs (2) }\end{array}$ & $\begin{array}{c}\text { Man: 3 vs } \\
\text { 4_5 (1) vs (2) }\end{array}$ & \multicolumn{2}{c}{$\begin{array}{c}\text { >40 Man: } \\
\text { 3 vs 4 (1) vs (2) }\end{array}$} & $\begin{array}{c}>40 . \text { Man: } \\
\text { 3 vs 4_5 (1) vs (2) }\end{array}$ & $\begin{array}{c}>40 . \text { Man: 3 vs } \\
4 \text { (1) vs (2) }\end{array}$ \\
\hline $\begin{array}{c}\text { Intensity } \\
\text { normalized @ }\end{array}$ & 386 & 386 & 386 & 548 & 386 & 386 & 548 \\
\hline $\begin{array}{c}\text { BA @ wave- } \\
\text { length }\end{array}$ & $\begin{array}{c}0.80 @ 459 \\
(0.77 @ 502)\end{array}$ & $\begin{array}{c}0.78 @ 488 \\
(0.77 @ 502)\end{array}$ & $\begin{array}{c}0.91 @ 459 \\
(0.91 @ 502)\end{array}$ & $0.87 @ 390$ & $0.79 @ 401$ & $0.91 @ 488$ & $\begin{array}{c}0.89 @ 383 \\
(084 @ 401)\end{array}$ \\
\hline Cut-off & $0.565(0.2)$ & $0.278(0.202)$ & $0.565(0.193)$ & 14.150 & 1.020 & 0.278 & 12.755 \\
\hline Average (1) & $0.730(0.229)$ & $0.324(0.228)$ & $0.906(0.283)$ & 9.906 & 1.111 & 0.396 & 9.411 \\
\hline Average (2) & $0.409(0.133)$ & $0.195(0.137)$ & $0.485(0.148)$ & 16.874 & 0.965 & 0.208 & 17.439 \\
\hline
\end{tabular}

Table 5. The average values of derivative ratios and 'cut-offs' that are indicated as bold letters in Table 3 and Fig. 9(b).

\begin{tabular}{cccccccc}
\hline Parameter & $\begin{array}{c}\text { Man: } \\
\text { 3(1) vs 4(2) }\end{array}$ & $\begin{array}{c}>40 . \text { Man: } \\
\text { 3(1) vs }>4 \_5(2)\end{array}$ & $\begin{array}{c}>40 . \text { Man: } \\
\text { 3(1) vs 4(2) }\end{array}$ & $\begin{array}{c}>40 . \text { Woman: } \\
\text { 3(1) vs }>4(2)\end{array}$ & $\begin{array}{c}>40 . \text { Woman: } \\
\text { 3(1) vs 4_5(2) }\end{array}$ \\
\hline Intensity normalized @ & 386 & 386 & 548 & 386 & 386 \\
\hline BA @ wavelength & $0.79 @ 484$ & $\begin{array}{c}0.84 @ 386(0.92 \\
@ 531)\end{array}$ & $0.95 @ 423$ & $0.84 @ 386$ & $0.84 @ 386$ \\
\hline Cut-off & -0.029 & $0.052(-0.008)$ & -0.126 & 0.063 & 0.063 \\
\hline Average (1) & -0.035 & $0.061(-0.012)$ & 0.290 & 0.078 & 0.078 \\
\hline Average (2) & -0.019 & $0.046(-0.006)$ & -0.335 & 0.043 & 0.044 \\
\hline
\end{tabular}

The age and the LOD dependent changes are mainly related to the structure of collagen. However, collagen and elastin (the main fluorophores in the disc) emit fluorescence bands that highly overlap. Therefore it was not possible to follow the changes in the disc by the fluorescence spectra, but it was possible to recognize the disc LOD that is essential for medical practice.

\section{Conclusions}

The results based on fluorescence spectra reveal subtle LOD-dependent biochemical changes taking place in human IVD material. These changes cannot be tracked by current diagnostic modalities (MRI) and can be revealed only if gender and age of patients are taken into account. The findings create a background for the design of equipment and the design of experiment of more advanced clinical trials.

FT-IR absorption and Raman scattering spectra demonstrated the age dependences of a few components. The Raman peak at $2707 \mathrm{~cm}^{-1}$ seems promising for recognition of lumbar IVD LOD, but a higher number of specimens is necessary.

Optical diagnostics shows the capability to discriminate aging versus degeneration processes in both genders.

\section{Acknowledgements}

The authors acknowledge prof. V. Šablinskas and the Centre of Spectroscopic Characterization of Materials and Electronic/Molecular Processes (Scientific Infrastructure SPECTROVERSUM) at the Lithuanian National Centre for Physical Sciences and Technology for the use of FT-IR and Raman spectroscopic equipment and dr. L. Neverauskienè from Patologijos Diagnostika, Ltd. for the preparation of the samples.

\section{References}

[1] J.P.G. Urban and S. Roberts, Degeneration of the intervertebral disc, Arthritis Res. Ther. 5(3), 120-130 (2003), https://doi.org/10.1186/ar629 
[2] T. Tan, S.L. Borkowski, S. Sangiorgio, P. Campbell, and E. Ebramzadeh, Imaging criteria for the quantification of disc degeneration: A systematic review, J. Bone Joint Surg. 3(2), 1-10 (2015), https://doi.org/10.2106/JBJS.RVW.N.00056

[3] L.M. Benneker, P.F. Heini, S.E. Anderson, M. Alini, and K. Ito, Correlation of radiographic and MRI parameters to morphological and biochemical assessment of intervertebral disc degeneration, Eur. Spine J. 14(1), 27-35 (2005), http:// doi.org/10.1007/s00586-004-0759-4

[4] C. Pfirrmann, A. Metzdorf, M. Zanetti, J. Hodler, and N. Boos, Magnetic resonance classification of lumbar intervertebral disc degeneration, Spine 26(17), 1873-1878 (2001), https://doi. org/10.2147/JPR.S122380

[5] G. Livshits, M. Popham, I. Malkin, P.N. Sambrook, A.J. MacGregor, T. Spector, and F.M.K. Williams, Lumbar disc degeneration and genetic factors are the main risk factors for low back pain in women: the UK Twin Spine Study, Ann. Rheum. Dis. 70(10), 1740-1745 (2011), https://doi. org/10.1136/ard.2010.137836

[6] K. Luoma, H. Riihimaki, R. Luukkonen, R. Raininko, E. Viikari-Juntura, and A. Lamminen, Low back pain in relation to lumbar disc degeneration, Spine 25(23), 487-492 (2000), https://doi. org/10.1097/00007632-200002150-00016

[7] M. Hancock, C. Maher, P. Macaskill, J. Latimer, W. Kos, and J. Pik, MRI findings are more common in selected patients with acute low back pain than controls? Eur. Spine J. 21(2), 240-246 (2012), https://doi.org/10.1007/s00586-011-1955-7

[8] M.A. van den Bosch, W. Hollingworth, A.L. Kinmonth, and A.K. Dixon, Evidence against the use of lumbar spine radiography for low back pain, Clin. Radiol. 59(1), 69-76 (2004),https://doi. org/10.1016/j.crad.2003.08.012

[9] B. Schenk, P.A. Brouwer, W.C. Peul, and M.A. van Buchem, Percutaneous laser disk decompression: a review of the literature, AJNR Am. J. Neuroradiol. 27(1), 232-235 (2006).

[10]R. Alfano and Y. Pu, Optical biopsy for cancer detection, in: Lasers for Medical Applications, ed. H. Jelinkova (Woodhead Publishing
Limited, 2013) pp. 325-367, https://doi. org/10.1533/9780857097545.3.325

[11]C. af Klinteberg, J. Wang-Nordman, C. Lindquist, K. Svanberg, and A. Vaitkuviene, Laser induced fluorescence studies of premalignant and benign lesions in the female genital tract, Proc. SPIE 3197, 34-40 (1997), https://doi.org/10.1117/12.297947

[12] M.J. DeWeert, J. Oyama, E. McLaughlin, E. Jacobson, J. Hakansson, G.S. Bignami, U.P. Gustafsson, P. Troy, V. Poskiene, K. Kriukelyte, et al., Analysis of spatial variability in hyperspectral imagery of the uterine cervix in vivo, Proc. SPIE 4959, 67-76 (2003), https://doi.org/10.1117/12.479495

[13]T. Hoell, G. Huschak, A. Beier, G. Hüttmann, Y. Minkus, H.J. Holzhausen, and H.J. Meisel, Auto fluorescence of intervertebral disc tissue: A new diagnostic tool, Eur. Spine J., 15 (Supplement 3), 345-353 (2006), https://doi.org/10.1007/s00586006-0157-1

[14]D. Varanius, G. Terbetas, J.V. Vaitkus, and A. Vaitkuviene, Spinal hernia tissue autofluorescence spectrum, Lasers Med. Sci. 28(2), 423-430 (2013), https://doi.org/10.1007/s10103-012-1077-4

[15]B. Gefvert, Raman Spectroscopy: Spectroscopy system outperforms MRI for invasive cancer detection, BioOptics World 10(9) (2017), https:// www.bioopticsworld.com/articles/print/volume-10/issue-9/raman-spectroscopy-spectroscopy-system-outperforms-mri-for-invasive-cancer-detection.htm

[16]R Core Team, $R: A$ Language and Environment for Statistical Computing ( $\mathrm{R}$ Foundation for Statistical Computing, Vienna, Austria, 2016), https://www.R-project.org

[17]D. Hopkins, Chemometrics in action. Shoot-out 2002: transfer of calibration for content of active in a pharmaceutical tablet, NIR News 14(5), 1013 (2003), https://doi.org/10.1255/nirn.735

[18]T. Fawcett, An introduction to ROC analysis, Pattern Recognit. Lett. 27(8), 859-928 (2006), https://doi.org/10.1016/j.patrec.2005.10.010

[19]K.H. Brodersen, C.S. Ong, K.E. Stephan, and J.M. Buhmann, The balanced accuracy and its posterior distribution, in: Proceedings of the 20th International Conference on Pattern Recognition 
(ICPR) (IEEE, Istanbul, 2010), https://ieeexplore. ieee.org/document/5597285/

[20]S.-Y. Lin, M.-J. Li, and W.-T. Cheng, FT-IR and Raman vibrational microspectroscopies used for spectral biodiagnosis of human tissues, Spectroscopy 21(1), 1-30, https://doi. org/10.1155/2007/278765

[21]D. Naumann, Infrared spectroscopy in microbiology, in: Encyclopedia of Analytical Chemistry, ed. R. A. Meyers (John Wiley \& Sons Ltd, Chichester, 2000) pp. 102-131, https://doi. org/10.1002/9780470027318.a0117.pub2

[22]A. Adams, Intervertebral disc tissues, in: Mechanical Properties of Aging Soft Tissues, eds. B. Derby and R. Akhtar (Springer International Publishing, 2015) pp. 7-35, https://doi. org/10.1007/978-3-319-03970-1_2

[23]Z. Movasaghi, S. Rehman, and I. Rehman, Raman spectroscopy of biological tissues, Appl. Spectrosc. Rev. 42(5), 493-541 (2007), https:// doi.org/10.1080/05704920701551530

[24]M.N. Slipchenko, T.T. Le, H. Chen, and J.- X. Cheng, High-speed vibrational imaging and spectral analysis of lipid bodies by compound Raman microscopy, J. Phys. Chem. B 113(21), 7681-7686 (2009), https://doi.org/10.1021 ip902231y

[25]K. Czamara, K. Majzner, M.Z. Pacia, K. Kochan, A. Kaczor, and M. Baranska, Raman spectroscopy of lipids: A review, J. Raman Spectrosc. 46(1), 4-20 (2015), https://doi.org/10.1002/jrs.4607

[26]J. De Gelder, K. De Gussem, P. Vandenabeele, and L. Moens, Reference database of Raman spectra of biological molecules, J. Raman Spectrosc. 38(9), 1133-1147 (2007), https://doi.org/10.1002 irs.1734

[27]C. Krafft, L. Neudert, T. Simat, and R. Salzer, Near infrared Raman spectra of human brain lipids, Spectrochim. Acta A Mol. Biomol. Spec- trosc. 61(7), 1529-1535 (2005), https://doi. org/10.1016/j.saa.2004.11.017

[28]D.S.J. Choy, Percutaneous laser disc decompression: history and scientific rationale, Tech. Reg. Anesth. Pain Manag. 9(1), 50-55 (2005), https:// doi.org/10.1053/j.trap.2005.01.005

[29] V.E. Arpinar, S. Rand, A. Klein, D. Maiman, and L.T. Muftuler, Changes in perfusion and diffusion in the endplate regions of degenerating intervertebral discs: A DCE-MRI study, Eur. Spine J. 24(11), 2458-2467 (2015), https://doi. org/10.1007/s00586-015-4172-y

[30]D. Kurouski, R.P. Van Duyne, and I.K. Lednev, Exploring the structure and formation mechanism of amyloid fibrils by Raman spectroscopy: a review, Analyst 140(15), 4967-4980 (2015), https://doi.org/10.1039/C5AN003420

[31]S. Arya, A. Kumari, V. Dalal, M. Bhattacharya, and S. Mukhopadhyay, Appearance of annular ringlike intermediates during amyloid fibril formation from human serum albumin, Phys. Chem. Chem. Phys. 17, 22862-22871 (2015), https://doi.org/10.1039/C5CP03782D

[32]C. Ladefoged, O. Fedders, and O.F. Petersen, Amyloid in intervertebral discs: A histopathological investigation of surgical material from 100 consecutive operations on herniated discs, Ann. Rheum. Dis. 45(3), 239-243 (1986).

[33]R. Dacosta, H. Andersson, and B. Wilson, Molecular fluorescence excitation-emission matrices relevant to tissue spectroscopy, Photochem. Photobiol. 78(4), 384-392 (2003), https://doi.org/10.1562/00318655(2003)0780384MFEMRT2.0.CO2

[34]A.C. Croce and G. Bottiroli, Autofluorescence spectroscopy and imaging: a tool for biomedical research and diagnosis, Eur. J. Histochem. 58(4), 320-337 (2014), https://doi.org/10.4081/ ejh.2014.2461 


\title{
OPTINĖS SPEKTROSKOPIJOS METODAI STUBURO TARPSLANKSTELINIO DISKO DEGENERACIJOS DIAGNOSTIKAI
}

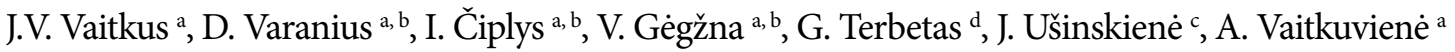 \\ ${ }^{a}$ Vilniaus universiteto Fotonikos ir nanotechnologiju institutas, Vilnius, Lietuva \\ ${ }^{\mathrm{b}}$ Vilniaus universiteto Gyvybès moksly centro Biomoksly institutas, Vilnius, Lietuva \\ ${ }^{\mathrm{c}}$ Nacionalinis vėžio institutas, Vilnius, Lietuva \\ ${ }^{d}$ Vilniaus universiteto Medicinos fakultetas, Vilnius, Lietuva
}

\section{Santrauka}

Stuburo tarpslankstelinio disko degeneracijos laipsnis gali turèti įtakos parenkant gydymo strategiją, todèl ieškomi metodai, leisiantys tai atlikti chirurgo darbo vietoje. Šiame darbe atlikta infraraudonosios šviesos sugerties, Ramano sklaidos ir fluorescencijos spektru analizé, atliekant skirtingų spektrinių požymių grupių méginių palyginimą statistiniais metodais.

Tyrime dalyvavo 37 pacientai ( 27 moterys ir 10 vyrų; vidutinis tiriamujų amžius 48,2 metai). Méginiai buvo paimti iš juosmeninès stuburo srities. Nustatyta 3 -as $(40,5 \%)$, 4 -tas $(48,6 \%)$ ir 5-tas (10,8 \%) degeneracijos lygmuo pagal Pfirrmanno degeneracijos vertinimo metodiką.

Visais trimis tyrimo metodais atrasti požymiai priklauso nuo pacientų amžiaus, lyties ir disko degeneracijos laipsnio.

Nustatyta, kad duomenų sklaida skirtinguose mèginiuose juos tiriant infraraudonosios šviesos sugerties ir Ramano sklaidos metodais yra per didelè. Gauti rezultatai nèra pakankamai patikimi, kad siūlomą metodą galètume rekomenduoti ar taikyti nustatant tarpslankstelinio disko degeneraciją. Su tarpslankstelinio disko degeneracija galimai susijusi Ramano sklaidos spektrų komponentą, išskirtą ties $2707 \mathrm{~cm}^{-1}$, tikslinga tirti pasitelkiant didesnị kiekị mėginių.

Fluoroforų, esančių audiniuose, fluorescencijos spektrai persikloja, tačiau atrastos spektro sritys, kuriose rasti požymiai pakankamai patikimai leidžia ịvertinti disko degeneracijos laipsnị ir aptikti su tuo susijusius tarpslankstelinio disko biocheminius pokyčius. Šios išvados galètų lemti pažangesnių eksperimentinių klinikinių tyrimų projektus ateityje.

Optinè diagnostika teikia galimybę atskirti senéjimo ir degeneracijos procesus abiems lytims. 